\title{
Hydralazine, antinuclear antibodies, and the lupus syndrome
}

\author{
R MANSILLA-TINOCO, S J HARLAND, P J RYAN, R M BERNSTEIN, C T DOLLERY, \\ G R V HUGHES, C J BULPITT, A MORGAN, J MARY JONES
}

\begin{abstract}
The incidence of patients with positive antinuclear antibody test results rose during three years of treatment with hydralazine. At the end of that period over half of the patients (both rapid and slow acetylators) had titres exceeding $1 / 20$, but the rate of rise was faster in the slow acetylators than in the rapid. There was a significant relation between the cumulative dose of hydralazine and the proportion of patients found to have antinuclear factor. Fewer black patients had positive test results than white. Patients whose antinuclear antibody test results changed from negative to positive during the study showed this change five to 26 months after beginning treatment. Some patients showed a substantial fall in antinuclear antibody titre even though hydralazine was continued.
\end{abstract}

From these findings patients in whom test results for antinuclear antibody became positive during treatment with hydralazine need not have the drug stopped unless they have clinical features of the lupus syndrome.

\section{Introduction}

The vasodilator hydralazine was introduced as a hypotensive agent in 1950, when the only alternatives were the ganglionblocking drugs. It was used as sole treatment in doses of up to $3 \mathrm{~g}$ daily. Treatment failures were common and there were many serious side effects. Some $5-10 \%$ of patients developed a syndrome resembling systemic lupus erythematosus with myalgia, arthralgia, fever, positive antinuclear antibody test results, and LE cells in their blood ${ }^{1-3}$; hence the drug fell into disuse, especially in Britain.

The toxicity of hydralazine was known to be dose related, however, and the lupus syndrome was rare when doses of less than $200 \mathrm{mg}$ daily were used. ${ }^{4-6}$ The drug is metabolised by acetylation and the lupus syndrome occurred almost exclusively in patients of the slow acetylator phenotype.$^{6-8}$ The availability of the beta-receptor-blocking drugs, which controlled the reflex tachycardia and palpitations caused by the vasodilator, resulted in renewed interest in hydralazine. ${ }^{9}$

Hydralazine is now widely used as the third step in the socalled "step-care" treatment of hypertension, in which the first and second steps are a diuretic and beta-adrenergic blocker.

Royal Postgraduate Medical School, Hammersmith Hospital, London W12 0HS

R MANSILLA-TINOCO, $\mathrm{MB}$, honorary registrar, department of clinical pharmacology

S J HARLAND, MRCP, registrar, department of clinical pharmacology

P J RYAN, FRACP, honorary registrar, department of medicine

$R$ M BERNSTEIN, MRCP, senior registrar, department of medicine

C T DOLLERY, MB, FRCP, professor of clinical pharmacology

G R V HUGHES, MD, FRCP, senior lecturer in medicine (rheumatology)

C J BULPITT, MD, senior lecturer

Ciba Geigy, Horsham, Sussex RH12 4AB

A MORGAN, SRN, research assistant

Institute of Cancer Research, Royal Cancer Hospital, Sutton, Surrey SM2 5PX

J MARY JONES, MSC, statistician
Widespread use of the drug has led to a few cases of hydralazineinduced lupus syndrome, and we decided to reinvestigate the immunological and clinical features of patients undergoing prolonged treatment with the drug.

\section{Patients}

The study was conducted over three years, and the subjects were drawn from 221 patients attending the hypertension clinic at Hammersmith Hospital who were being treated with hydralazine.

One hundred and sixty-two patients agreed to be phenotyped as slow or rapid acetylators of sulphadimidine, and form the study group. Forty patients were studied at the time of starting hydralazine or within the next three months (baseline data); the remaining 122 patients had already taken hydralazine for more than three months (table I). All the patients were taking more than one antihypertensive drug during the study: most were taking a beta-adrenergic blocker, usually propranolol or atenolol, plus a thiazide.

Seven patients attending the clinics at Hammersmith Hospital developed the lupus syndrome during the study period, though only two of these were in the study group. Blood samples and clinical details were also available from six patients with hydralazine-induced lupus syndrome seen at other hospitals which collaborated with the study. The seven patients from Hammersmith Hospital who developed the lupus syndrome were compared with the other patients in the study, and all 13 patients with hydralazine-induced lupus syndrome were analysed for the clinical features of the disease.

TABLE I-Details of patients studied

\begin{tabular}{|c|c|c|c|}
\hline . & $\begin{array}{c}\text { No }(\%) \text { of } \\
\text { patients } \\
\text { (total }=162 \\
100 \%)\end{array}$ & $\begin{array}{c}\text { No }(\%) \text { with } \\
\text { antinuclear } \\
\text { antibody titre } 1 / 20 \\
\text { (total }=76 ; \\
46.9 \%)\end{array}$ & $\begin{array}{c}\text { No }(\%) \text { of } \\
\text { patients with } \\
\text { hydralazine- } \\
\text { induced lupus } \\
\text { syndrome } \\
\text { (total }=7\left[2^{*}\right] ; \\
\left.4 \cdot 3 \%\left[1 \cdot 2^{*}\right)^{*}\right]\end{array}$ \\
\hline $\begin{array}{l}\text { Acetylator phenotype: } \\
\text { Slow } \\
\text { Rapid }\end{array}$ & $\begin{array}{l}87(53 \cdot 7) \\
75(46 \cdot 3)\end{array}$ & $\begin{array}{l}44(50 \cdot 6) \\
32(42 \cdot 6)\end{array}$ & $\begin{array}{l}6(6 \cdot 9) \\
1(1 \cdot 3)\end{array}$ \\
\hline $\begin{array}{l}\text { Sex: } \\
\quad \text { Men } \\
\text { Women }\end{array}$ & $\begin{array}{l}96(59 \cdot 3) \\
66(40 \cdot 7)\end{array}$ & $\begin{array}{l}40(41 \cdot 6) \\
36(54 \cdot 5)\end{array}$ & $\begin{array}{l}1(1 \cdot 0) \\
6(9 \cdot 1)\end{array}$ \\
\hline $\begin{array}{l}\text { Ethnic group: } \\
\text { Caucasian } \\
\text { Black } \\
\text { Indian subcontinent }\end{array}$ & $\begin{array}{c}125(77 \cdot 2) \\
23(14 \cdot 2) \\
14(8 \cdot 6)\end{array}$ & $\begin{array}{r}64(51 \cdot 2) \\
5(21 \cdot 7) \\
7(50 \cdot 0)\end{array}$ & $\begin{array}{l}6(4 \cdot 8) \\
1(4 \cdot 3) \\
0\end{array}$ \\
\hline
\end{tabular}

Mean age 59 years.

the 162 patients who agreed to be phenotyped for the study.

\section{Methods}

Patients were seen every four months and blood samples drawn for immunological investigations. Samples were allocated a code number and these coded samples used for all determinations. Antinuclear antibody tests were performed by indirect immunofluorescence on rat liver sections and with a rabbit anti-whole immunoglobulin fluorescent conjugate (Wellcome Laboratories). ${ }^{10}$ Sera were screened at a dilution of $1 / 20$ (phosphate-buffered saline): positive sera were titrated to a dilution of $1 / 2560$. To assess the reproducibility of the method 10 samples taken for routine autoantibody testing were coded and measured in duplicate on three separate occasions.

Antibodies to native deoxyribonucleic acid were measured by Farr assay, ${ }^{11}$ and antibodies to extractable nuclear antigens by counterimmunoelectrophoresis. ${ }^{10}$

Patients were divided into 12 groups according to their total intake of hydralazine, so that there were about the same number of patients 
in each dose range. Results in these dose ranges were analysed as a single block. There were too few patients contributing results to every block to confine the analysis to sequential changes in individuals. Patients were also classified by sex, ethnic group, and according to whether they were slow or rapid acetylators (acetylator phenotype determined by the method of Price Evans, second dosage schedule ${ }^{12}$ ). The effect of these three variables on the probability of a positive antinuclear antibody test result, allowing for a dose effect, was investigated by fitting various logistic models to the data using the computer package GLIM (Generalised Linear Interactive Modelling). ${ }^{13}$ The midpoints of the dose ranges were taken as the dose values. For each model fitted the number of degrees of freedom and the model's deviance (twice the maximised log likelihood) were generated by GLIM. The statistical significance of a component in a model was obtained by fitting the model with and without this component. The difference in deviance between the two models is distributed approximately as a $\chi^{2}$ statistic with degrees of freedom equal to the difference in degrees of freedom of the two models.

Differences in dose-response in the various subgroups were examined. Tests were made to see whether there was a significant linear trend on the dose and whether there was a significant difference in the proportions of patients with positive antinuclear antibody test results between the subgroups.

Symptom questionnaire-The patients with the lupus syndrome all had moderately severe symptoms. To investigate the possibility that there were unrecognised cases with milder symptoms we sent a questionnaire to 116 patients taking hydralazine and 421 patients matched for age and sex receiving other antihypertensive treatment, mainly diuretics or beta-blocking drugs alone or in combination. The patients were identified from records of the DHSS hypertension clinic computer project. Questions were asked about symptoms that could form part of the lupus syndrome-pain in the joints of the hands and other joints, tingling or numbness in the hands or feet, cold hands or feet, a red rash on the face or elsewhere, weakness, loss of appetite, and night sweats-and about symptoms that might result from the vasodilator action of hydralazine-flushing of the face, the heart thumping or missing a beat, bloodshot eyes, and shaking of the hands.

\section{Results}

The results presented come from all 221 patients from the hypertension clinic (503 antinuclear antibody analyses) or from the study group of 162 patients whose acetylator phenotype was determined.

\section{ALL PATIENTS}

The influence of total hydralazine intake on a positive antinuclear antibody test result at three titres $(\geqslant 1 / 20, \geqslant 1 / 40, \geqslant 1 / 160)$ was analysed. A significant regression of the proportion of patients with a positive result on the amount of hydralazine consumed was seen at each titre $(p<0.001$, fig 1$)$. The quantitative difference in proportion

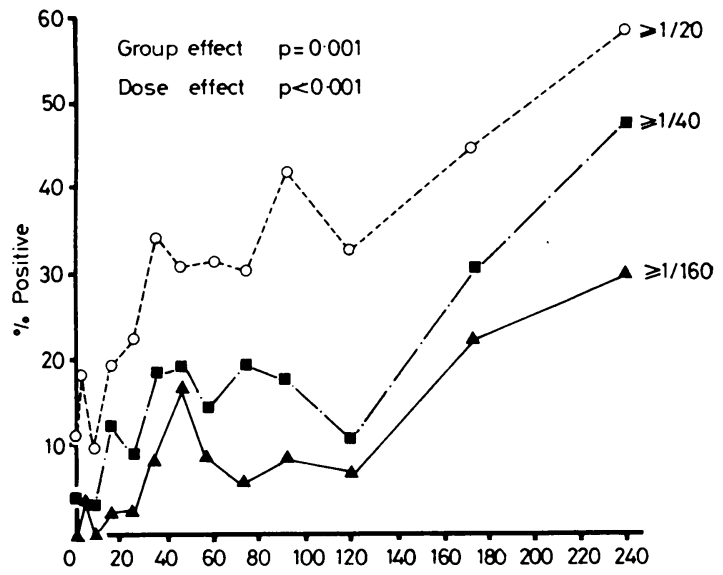

FIG 1-All patients : influence of cumulative intake of hydralazine on incidence of positive antinuclear antibody test results at three titres. between the titres was also highly significant $(p<0.001)$. The rate of increase in the proportion of patients with antinuclear antibodies was not significantly different between the groups $(p=0 \cdot 61)$. Figure 2 shows a slight difference between the proportions of men and women with positive antinuclear antibody test results, but this was not significant $(p=0 \cdot 24)$. Of all 221 patients attending the clinic, $33(15 \%)$ were black. The proportion of black patients with antinuclear antibody titres positive at levels of $1 / 20$ was significantly less $(p<0.001)$ than

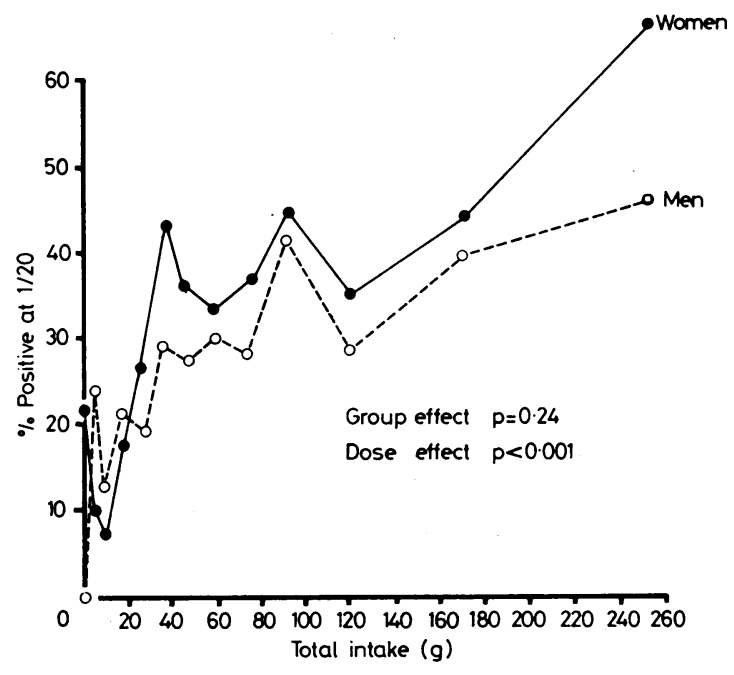

FIG 2-Influence of sex on accumulation of antinuclear antibodies.

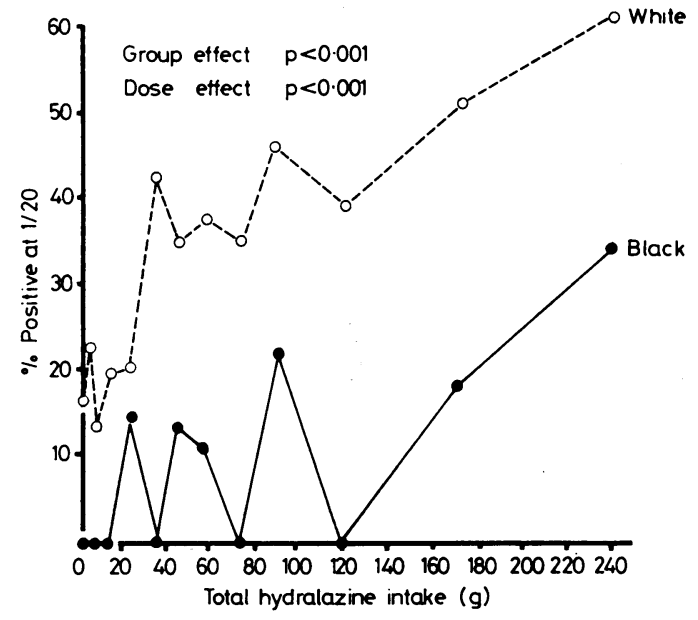

FIG 3-Influence of race on accumulation of antinuclear antibodies.

in the 162 white patients, though the slopes of the relations between cumulative dose and positive antinuclear antibody test results were similar (fig 3). The number of patients from the subcontinent of India was smaller but their frequency of a positive antinuclear antibody test results was similar to that of the whites.

\section{SLOW AND RAPID ACETYLATORS}

Rapid acetylators had a significantly lower incidence of positive antinuclear antibody test results than slow acetylators $(p<0.001)$ but the main difference was in the rate of development of positive test results (fig 4). Slow acetylators had positive results soon after starting treatment and about half had antinuclear antibody titres of $1 / 20$ after $50 \mathrm{~g}$ hydralazine: thereafter there was little change in the proportion with a positive test results. Rapid acetylators developed antinuclear antibodies more slowly, though after a cumulative dosage of $200 \mathrm{~g}$ half gave positive results at a titre of $1 / 20$. 


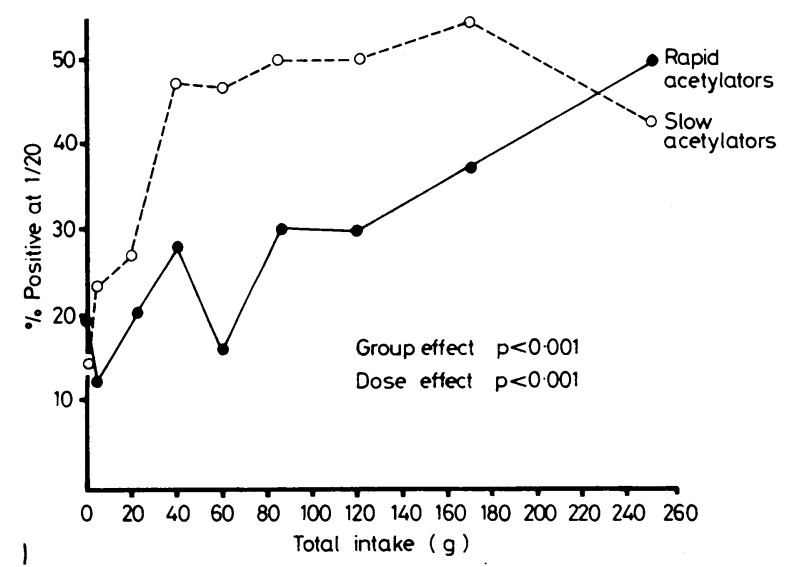

FIG 4-Influence of acetylator phenotype on accumulation of antinuclear antibodies.

\section{CONVERSION OF ANTINUCLEAR ANTIBODY TITRE}

In 32 patients ( 16 slow and 16 rapid acetylators) antinuclear antibody test results converted from negative to positive during the study period. The mean duration of treatment before conversion was 23 months for rapid acetylators and 15 months for slow acetylators.

Of the $\mathbf{4 0}$ patients studied from the start of treatment, seven had positive antinuclear antibody test results at the outset (five slow and two rapid acetylators) and nine of the remainder developed positive results during treatment (five slow and four rapid acetylators). The time from the beginning of treatment to the first positive antinuclear antibody test result varied from five to 17 months (mean 9.6 months).

Unexpectedly 13 patients had a decrease in antinuclear antibody titre of two or more dilutions or returned to giving a negative test result. These changes in titre exceed the error of the method, which had very good reproducibility (table II).

TABLE II-Results of blind study of variability of repeated testing of sera for antinuclear antibody titre (assays performed in duplicate)

\begin{tabular}{clll}
\hline Sample & \multicolumn{1}{c}{ First assay } & \multicolumn{1}{c}{ Second assay } & \multicolumn{1}{c}{ Third assay } \\
\hline A & $1 / 640 ; 1 / 640(\mathrm{H})$ & $1 / 640 ; 1 / 640(\mathrm{H})$ & $1 / 640 ; 1 / 640(\mathrm{H})$ \\
B & $1 / 40 ; 1 / 20(\mathrm{H})$ & $1 / 40 ; 1 / 40(\mathrm{H})$ & $1 / 20 ; 1 / 40(\mathrm{H})$ \\
$\mathrm{C}$ & $1 / 160 ; 1 / 320(\mathrm{H})$ & $1 / 160 ; 1 / 160(\mathrm{H})$ & $1 / 160 ; 1 / 160(\mathrm{H})$ \\
$\mathrm{D}$ & $1 / 2560 ; 1 / 2560(\mathrm{~S})$ & $1 / 2560 ; 1 / 2560(\mathrm{~S})$ & $1 / 2560(\mathrm{~S}) ; 1 / 2560$ \\
$\mathrm{E}$ & $1 / 80 ; 1 / 160(\mathrm{~S})$ & $1 / 80 ; 1 / 80(\mathrm{~S})$ & $1 / 80 ; 1 / 160(\mathrm{~S})$ \\
$\mathrm{F}$ & $1 / 40 ; 1 / 40(\mathrm{H})$ & $1 / 40 ; 1 / 20(\mathrm{H})$ & $1 / 20 ; 1 / 20(\mathrm{H})$ \\
G & $1 / 40 ; 1 / 20(\mathrm{H})$ & $1 / 40 ; 1 / 40(\mathrm{H})$ & $1 / 20 ; 1 / 40(\mathrm{H})$ \\
$\mathrm{H}$ & $1 / 160 ; 1 / 320(\mathrm{H})$ & $1 / 320 ; 1 / 320(\mathrm{H})$ & $1 / 160 ; 1 / 160(\mathrm{H})$ \\
I & $1 / 320 ; 1 / 640(\mathrm{~S})$ & $1 / 640 ; 1 / 640(\mathrm{~S})$ & $1 / 320 ; 1 / 320(\mathrm{~S})$ \\
J & $1 / 1280 ; \mathrm{ND}$ & $1 / 2560 ; 1 / 2560(\mathrm{H})$ & $1 / 1280 ; 1 / 1280$ \\
\hline
\end{tabular}

$\mathrm{H}=$ Homogenous. $\mathbf{S}=$ Speckled.

\section{PATIENTS WITH LUPUS SYNDROME}

Table I shows the characteristics of the patients whose phenotype was determined. Patients with the lupus syndrome differed from the remainder in being predominantly slow acetylators and female. Their cumulative intake of hydralazine and mean duration of treatment were not significantly different from those of the slow acetylators who did not develop the lupus syndrome. Tables III and IV show the clinical and laboratory features of these patients and of the six patients from other hospitals who developed the lupus syndrome.

TABLE III-Physical signs and symptoms in 13 patients who developed lupus syndrome

\begin{tabular}{|c|c|c|c|c|c|}
\hline Physical signs & $\begin{array}{c}\text { No of } \\
\text { patients }\end{array}$ & \multicolumn{3}{|c|}{ Symptoms } & $\begin{array}{c}\text { No of } \\
\text { patients }\end{array}$ \\
\hline $\begin{array}{l}\begin{array}{l}\text { Swollen joints } \\
\text { Weight loss } \ldots\end{array} \quad \ldots \\
\text { Fever .. } \\
\text { Splenomegaly } \\
\text { Vasculitis } \\
\text { Central nervous } \\
\text { lo system }\end{array}$ & $\begin{array}{l}\cdots \\
\cdots \\
\cdots \\
\cdots\end{array}$ & $\begin{array}{l}\text { Arthralgia } \\
\text { Myalgia } \\
\text { Malaise }\end{array}$ & $\because$ & $\because$ & $\begin{array}{r}13 \\
5 \\
9\end{array}$ \\
\hline
\end{tabular}

TABLE IV-Laboratory findings in 13 patients who developed lupus syndrome while taking hydralazine

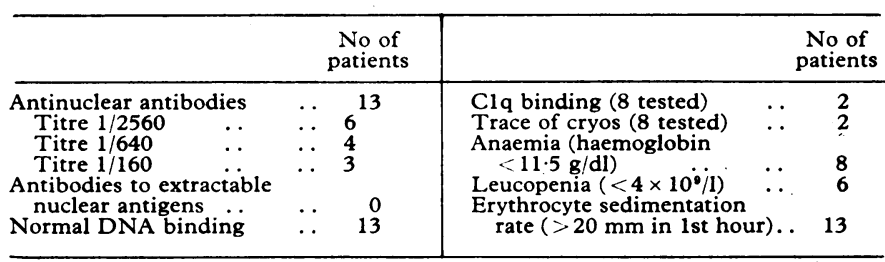

\section{SYMPTOM QUESTIONNAIRE}

The main interest of the questionnaire results was the significantly lower incidence of symptoms such as pain in the joints of the hands and swelling of the face in the patients treated with hydralazine. These patients also had a lower incidence of other symptoms such as rash on the face and pain in the other joints, though this did not reach statistical significance (table V). As it is unlikely that hydralazine has a specific beneficial effect on such symptoms a more probable explanation is that hydralazine was stopped in patients who developed such symptoms whether or not they were due to the drug.

TABLE $\mathrm{v}-S y m p t o m s$ reported by patients taking antihypertensive drugs

\begin{tabular}{|c|c|c|c|}
\hline & $\begin{array}{c}\text { No (ó) taking } \\
\text { hydralazine } \\
(n=116)\end{array}$ & $\begin{array}{c}\text { No }(\%) \text { not taking } \\
\text { hydralazine } \\
(\mathbf{n}=\mathbf{4 2 1})\end{array}$ & $\mathrm{p}$ \\
\hline $\begin{array}{l}\text { Pains in joints of hand } \\
\text { Pains in other joints } \\
\text { Red rash on face } \\
\text { Swelling of face } \\
\text { Decreased appetite } \\
\text { Sweating at night } \\
\text { Palpitations } \\
\text { Heart races at rest } \\
\text { Face flushed } \\
\text { Impotence }\end{array}$ & $\begin{array}{l}12(10) \\
23(20) \\
4(3) \\
1(1) \\
6(5) \\
21(18) \\
34(29) \\
14(12) \\
24(21) \\
64(55)\end{array}$ & $\begin{aligned} 88(21) \\
105(25) \\
21(5) \\
25(6) \\
42(10) \\
84(20) \\
143(34) \\
84(20) \\
118(28) \\
101(24)\end{aligned}$ & $\begin{array}{c}<0.02 \\
\text { NS } \\
\text { NS } \\
<0.06 \\
\text { NS } \\
\text { NS } \\
\text { NS } \\
<0.07 \\
\text { NS } \\
<0.0001\end{array}$ \\
\hline
\end{tabular}

NS $=$ Not significant

This explanation finds some support from findings about symptoms more likely to be related to the vasodilator action. Patients treated with hydralazine complained less of heart racing while at rest, though this did not reach statistical significance $(p=0 \cdot 07)$. Concomitant treatment with beta-adrenoceptor-blocking drugs may have further reduced the frequency of this symptom. One unexpected finding was a much higher incidence of sexual problems, especially with erection, in men being treated with hydralazine. This may have been related to the vasodilator effect.

\section{Discussion}

The hydralazine-induced lupus syndrome is unpleasant for the patient, though it appears to be fully, but slowly, reversible when the drug is stopped. The incidence of the lupus syndrome is greater in women, in slow acetylators, and in people of the HLA type DR4. All patients with the lupus syndrome had antinuclear antibodies and one of the main objectives of the study was to assess the importance of a positive antinuclear antibody test result in patients who had no clinical manifestations of the lupus syndrome.

The proportion of patients taking hydralazine who had positive antinuclear antibody test results at titres of one in 20 rose with duration of treatment. The proportion rose more quickly in slow than in fast acetylators but after three years of treatment the proportion of positive results was similar; $54 \%$ in slow and $46 \%$ in fast acetylators. There was no significant difference in the incidence of a positive antinuclear antibody test result between the sexes. Thus there were important differences between the factors that influenced the development of antinuclear antibodies and the development of the lupus syndrome. A few antinuclear antibody titres were very high but there were large and unpredictable fluctuations in the titre, which much exceeded the reproducibility of the test system. A positive antinuclear antibody test result alone is of little predic- 
tive value in relation to the lupus syndrome as most positive results occur in patients with a low risk of developing the lupus syndrome.

The link between the development of an antinuclear antibody and the lupus syndrome is of considerable interest but appears to be indirect. Only patients with antinuclear antibodies develop the lupus syndrome but the proportion who do so must be small, as the incidence of a positive antinuclear antibody test result is $30-60 \%$ after three years of treatment but that of the lupus syndrome is only $1-3 \%$. Several genetic factors such as sex, acetylator state, and HLA type determine which patients develop lupus but do not influence the occurrence of antinuclear antibodies so we cannot be certain that antinuclear antibodies play any direct part in the pathogenesis of the disease. ${ }^{14-17}$ The presence of antinuclear antibodies does not appear to require any change in treatment unless there are other features that place the patient in a high-risk group or the patient has developed persistent symptoms.

\section{References}

${ }^{1}$ Anonymous. Immunogenetics and essential hypertension. Lancet 1978;ii: $409-10$.

${ }^{2}$ Perry HM Jr, Schroeder HA. Syndrome simulating collagen disease caused by hydralazine (Apresoline). 7 AMA 1954;154:670-3.

${ }^{3}$ Dustan HL, Taylor RD, Corcoron AC, Page IH. Rheumatic and febrile syndrome during prolonged hydralazine treatment. $\mathcal{F} A M A$ 1954;154: 23-9.
${ }^{4}$ Anonymous. Hydralazine. Lancet $1977 ; \mathrm{i}: 342-3$.

${ }^{5}$ Perry HMJ, Tan EM, Connoly SH, et al. Relationship of acetyl transferase activity to antinuclear antibodies and toxic symptoms in hypertensive patients treated with hydralazine. $\mathcal{F}$ Lab Clin Med 1970;76:114-25.

${ }^{6}$ Perry HMJ. Late toxicity to hydralazine resembling systemic lupus erythematosus or rheumatoid arthritis. Am f Med 1973;54:58-72.

${ }^{7}$ Condemi JJ, Moore-Jones D. Antinuclear antibodies following hydralazine toxicity. N Engl f Med 1967;276:486-91.

${ }^{8}$ Strandberg I, Boman G. Acetylator phenotype in patients with hydralazineinduced lupoid syndrome. Acta Med Scand 1976;200:367-71.

${ }^{9}$ Hansson L, Olander R, Aberg H. Treatment of hypertension with propranolol and hydralazine. Acta Med Scand 1971;190:531-4.

${ }^{10}$ Bresnihan B, Bunn C, Schneider ML, Hughes GRV. Antiribonucleoprotein antibodies in connective tissue diseases: estimation by counterimmunoelectrophoresis. $\mathrm{Br}$ Med f 1977; : $: 610-2$.

${ }^{11}$ Farr RS. A quantitative immunochemical measure of the primary interaction between IBSA and antibody. F Infect Dis $1958 ; 103: 239-62$.

${ }_{12}$ Price Evans DA. An improved and simplified method of detecting the acetylator phenotype. F Med Genet 1969;6:405-7.

${ }^{13}$ Baker RJ, Nelder JA. The GLIM system. Generalised Linear Interactive Modelling manual. Oxford: NAG, 1978.

${ }^{14}$ Fessel WJ. Systemic lupus erythematosus in the community, incidence, prevalence, outcome and first symptoms. The high prevalence in black women. Arch Intern Med 1974;134:1027-35.

${ }^{15}$ Wilson W, Hughes GRV. Rheumatic disease in Jamaica. A 3-year study. Ann Rheum Dis 1979;38:322.

${ }^{16}$ Siegel M, Lee SL. The epidemiology of systemic lupus erythematosus. Semin Arthritis Rheum 1973;3:1-54.

${ }^{17}$ Batchelor J, Welsh KI, Mansilla-Tinoco R, et al. Hydralazine-induced systemic lupus erythematosus: influence of HLA-DR and sex on susceptibility. Lancet $1980 ;$; :1107-9.

(Accepted 23 December 1981)

\section{Fatal overdose of theophylline simulating acute pancreatitis}

Aminophylline, a combination of theophylline and ethylenediamine, is widely prescribed as the oral bronchodilator Phyllocontin. Although fatal theophylline overdosage is well recognised, ${ }^{1}$ the clinical and biochemical features of acute pancreatitis have not been described in this syndrome.

\section{Case report}

A 53-year-old ex-foundry worker had previously been well except for exertional dyspnoea due to chronic obstructive airways disease. Treatment had included salbutamol by inhalation and cimetidine for dyspepsia, which had been stopped three months previously. There was no history of alcohol abuse or recent steroid or diuretic treatment. On the day of admission he awoke at 0300 to find his wife dead in bed. His children subsequently reported that by 0600 he was acutely short of breath, cold and sweaty, trembling, and uncommunicative. He vomited on his way to hospital and on arrival at 0830 was conscious, nauseated, and complaining of epigastric and central abdominal pain.

On examination he was shocked (pulse 150/minute, regular; blood pressure $90 / 50 \mathrm{~mm} \mathrm{Hg}$ ), tachypnoeic, restless, and tremulous but not feverish. His abdomen was distended with diminished bowel sounds and epigastric tenderness.

Overdosage with an unknown substance was provisionally diagnosed; the stomach was aspirated and a coffee-ground material recovered. Immediate investigations showed supraventricular tachycardia, fluid levels on a plain abdominal $x$-ray film, leucocytosis, hypokalaemic metabolic acidosis, hyperglycaemia, glycosuria, and high serum amylase activity. The diagnosis was amended to acute pancreatitis. The table shows the results of subsequent relevant investigations.

Supportive treatment with intravenous fluids, blood, potassium, insulin, and gastric aspiration was begun. His tachycardia was controlled with intravenous verapamil, but he received no morphine. His condition deteriorated, and grand mal convulsions were followed by cardiorespiratory arrests, culminating in death a few hours later. Subsequent necropsy showed coronary atherosclerosis and pulmonary oedema. The stomach contained approximately 30 partially dissolved tablets, later identified as Phyllocontin, and $500 \mathrm{ml}$ of haemorrhagic fluid containing $526 \mathrm{mg}$ of this drug. The upper part of the jejunum was congested. The pancreas was normal macroscopically and microscopically. Postmortem liver and blood theophylline concentrations were $108 \mathrm{mg} / 1$ and $100 \mathrm{mg} / \mathrm{l}$ respectively, the therapeutic blood concentration being $10-20 \mathrm{mg} / \mathrm{l}$.

\section{Comment}

This case showed many of the previously described features of theophylline intoxication-namely hyperglycaemia, hypokalaemia, and metabolic acidosis. ${ }^{2}$ Despite the clinical picture and the appreciably raised serum amylase activity there was no evidence of pancreatitis at necropsy.

Hyperamylasaemia has not to our knowledge been previously documented in theophylline intoxication. It was, however, present in nearly $80 \%$ of patients with diabetic ketoacidosis in one study ${ }^{3}$ and did not often indicate pancreatitis. Isoenzyme studies showed it to be of salivary or pancreatic origin in equal numbers of patients. Our patient, although hyperglycaemic and acidotic, was not ketotic. This case

Results of relevant investigations (figures in parentheses are normal ranges)

\begin{tabular}{|c|c|c|c|c|c|c|c|c|}
\hline Time & $\begin{array}{l}\text { Serum potassium } \\
(\mathrm{mmol} / \mathrm{l})(3 \cdot 5-5 \cdot 3)\end{array}$ & $\underset{(\mathrm{mmol} 1)(2 \cdot 15-2 \cdot 63)}{\text { Serum calcium }}$ & $\mathrm{pH}$ & $\begin{array}{c}\text { Bicarbonate } \\
(\mathrm{mmol} / 1)(22-26)\end{array}$ & $\underset{(\mathrm{mmol} / \mathrm{l})}{\text { Plasma glucose }}$ & $\underset{(\mathrm{g} / \mathrm{dl})}{\text { Haemoglobin }}$ & $\begin{array}{c}\text { White cell count } \\
\left(\times 10^{9} / 1\right)\end{array}$ & $\begin{array}{l}\text { Serum amylase } \\
(\mathrm{IU} / 1)(0-300)\end{array}$ \\
\hline $\begin{array}{l}0830 \\
1130 \\
1530\end{array}$ & $\begin{array}{l}2 \cdot 8 \\
3 \cdot 1 \\
3 \cdot 4\end{array}$ & $2 \cdot 48$ & $\begin{array}{l}7 \cdot 28 \\
7 \cdot 19\end{array}$ & $\begin{array}{l}14 \cdot 6 \\
12 \cdot 4\end{array}$ & $\begin{array}{l}20 \cdot 1 \\
15 \cdot 7 \\
14\end{array}$ & $\begin{array}{l}13 \cdot 5 \\
11 \cdot 8\end{array}$ & $\begin{array}{l}23 \cdot 1 \\
21 \cdot 6 \\
24 \cdot 3\end{array}$ & $\begin{array}{l}3980 \\
7150\end{array}$ \\
\hline
\end{tabular}

Conversion: SI to traditional units-Potassium: $1 \mathrm{mmol} / 1=1 \mathrm{mEq} / 1$. Serum calcium: $1 \mathrm{mmol} / 1 \approx 4 \mathrm{mg} / 100 \mathrm{ml}$. Bicarbonate: $1 \mathrm{mmol} / \mathrm{l}=1 \mathrm{mEq} / 1$. Plasma glucose: $1 \mathrm{mmol} / 1=18 \mathrm{mg} / 100 \mathrm{ml}$. 